2012s-07

\title{
The Growing Business of Mitigating Ecological Footprints
}

Aurélia L. Durand, Bernard Sinclair-Desgagné

\begin{tabular}{c}
\hline Série Scientifique \\
Scientific Series
\end{tabular}

\author{
Montréal \\ Avril 2012
}

(C) 2012 Aurélia L. Durand, Bernard Sinclair-Desgagné. Tous droits réservés. All rights reserved. Reproduction partielle permise avec citation du document source, incluant la notice (C).

Short sections may be quoted without explicit permission, if full credit, including (C) notice, is given to the source.
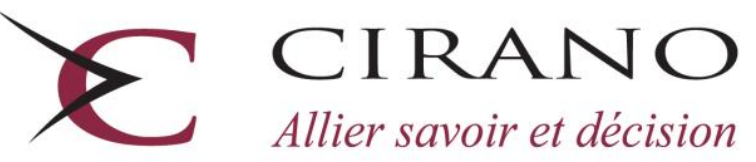

Allier savoir et décision

Centre interuniversitaire de recherche en analyse des organisations 


\section{CIRANO}

Le CIRANO est un organisme sans but lucratif constitué en vertu de la Loi des compagnies du Québec. Le financement de son infrastructure et de ses activités de recherche provient des cotisations de ses organisations-membres, d'une subvention d'infrastructure du Ministère du Développement économique et régional et de la Recherche, de même que des subventions et mandats obtenus par ses équipes de recherche.

CIRANO is a private non-profit organization incorporated under the Québec Companies Act. Its infrastructure and research activities are funded through fees paid by member organizations, an infrastructure grant from the Ministère du Développement économique et régional et de la Recherche, and grants and research mandates obtained by its research teams.

\section{Les partenaires du CIRANO}

\section{Partenaire majeur}

Ministère du Développement économique, de l'Innovation et de l'Exportation

\section{Partenaires corporatifs}

Autorité des marchés financiers

Banque de développement du Canada

Banque du Canada

Banque Laurentienne du Canada

Banque Nationale du Canada

Banque Royale du Canada

Banque Scotia

Bell Canada

BMO Groupe financier

Caisse de dépôt et placement du Québec

\section{CSST}

Fédération des caisses Desjardins du Québec

Financière Sun Life, Québec

Gaz Métro

Hydro-Québec

Industrie Canada

Investissements PSP

Ministère des Finances du Québec

Power Corporation du Canada

Rio Tinto Alcan

State Street Global Advisors

Transat A.T.

Ville de Montréal

\section{Partenaires universitaires}

École Polytechnique de Montréal

HEC Montréal

McGill University

Université Concordia

Université de Montréal

Université de Sherbrooke

Université du Québec

Université du Québec à Montréal

Université Laval

Le CIRANO collabore avec de nombreux centres et chaires de recherche universitaires dont on peut consulter la liste sur son site web.

Les cahiers de la série scientifique (CS) visent à rendre accessibles des résultats de recherche effectuée au CIRANO afin de susciter échanges et commentaires. Ces cahiers sont écrits dans le style des publications scientifiques. Les idées et les opinions émises sont sous l'unique responsabilité des auteurs et ne représentent pas nécessairement les positions du CIRANO ou de ses partenaires.

This paper presents research carried out at CIRANO and aims at encouraging discussion and comment. The observations and viewpoints expressed are the sole responsibility of the authors. They do not necessarily represent positions of CIRANO or its partners. 


\title{
The Growing Business of Mitigating Ecological Footprints
}

\author{
Aurélia L. Durand ${ }^{*}$,Bernard Sinclair-Desgagné ${ }^{*}$
}

\begin{abstract}
Résumé / Abstract
Au cours des dernières décennies, nombre de firmes polluantes et d'agences gouvernementales se sont mises à avoir recours à des fournisseurs spécialisés pour obtenir les produits et services nécessaires à la réduction de leur empreinte écologique. Ces fournisseurs constituent maintenant une industrie vaste et en pleine croissance, dont la taille est actuellement comparable à celle des secteurs aéronautique ou pharmaceutique. Jusqu'à présent, toutefois, l'interface entre vendeurs et acheteurs de technologies propres a été largement ignorée dans la littérature académique. On comprend donc encore mal la dynamique sousjacente de cette interaction, par conséquent son potentiel à créer de valeur tout en améliorant l'utilisation des ressources environnementales. Cet article propose d'abord un bref aperçu de l'histoire de l'écoindustrie, de son périmètre, de son développement récent et de ses perspectives de croissance. A la lumière de certains faits stylisés et des connaissances actuelles en économie de l'innovation et en marketing relationnel, nous analysons ensuite comment l'interaction entre les entreprises polluantes et leurs fournisseurs de technologies propres pourrait les amener à co-créer de la valeur. Nous mettons en évidence certains obstacles à cet état de chose, présentons leurs implications pour la politique publique et la stratégie d'entreprise, et esquissons finalement quelques avenues de recherche qui nous apparaissent prioritaires.
\end{abstract}

Mots clés : Technologies propres, innovation smithienne, échange relationnel, logique de service, co-création de valeur.

Over the past decades, polluting firms and government bodies have come to rely increasingly on specialized suppliers for the necessary goods, technologies and services that would alleviate their environmental footprint. These suppliers now form a large and growing industry, the so-called 'ecoindustry', which currently matches the aerospace and pharmaceutical sectors in size. So far, the interface between cleantech sellers and buyers has been mostly overlooked in the academic literature. As a result, its underlying dynamics and potential for value-creation - and a better environmental performance - are still poorly understood. This conceptual paper first offers an overview of the eco-industry's history and outlines its scope, recent development and growth potential. It then builds upon current knowledge in innovation economics and relationship marketing to analyze the evolving interactions between polluters and their cleantech suppliers towards value co-creation. Current barriers to this trend are next highlighted, the implications for public policy and business strategy are discussed, and some future research avenues are finally outlined.

Keywords: Environmental goods and services industry, Smithian innovation, relational exchange, service logic, value co-creation.

\footnotetext{
* Assistant Professor, Department of International Business, HEC Montréal, 3000 Chemin de la Côte-SainteCatherine, Montréal, Canada H3T 2A7, e-mail - aurelia.durand@ hec.ca.

${ }^{\dagger}$ Professor, Department of International Business, HEC Montréal, 3000 Chemin de la Côte-Sainte-Catherine, Montréal, Canada, H3T 2A7, e-mail - bsd@ @ec.ca.
} 


\section{Introduction}

One of the most remarkable economic events of the past decades surely is the emergence of a large specialized industry that focuses on mitigating the environmental impacts of human activity. Still insignificant in the late sixties, this so-called 'eco-industry' now compares with the aerospace and pharmaceutical sectors in size, employs more people than the automobile or chemical industries, accounts for important and fast-growing shares of GDPs and international trade, and holds currently close to eight percent of all awarded patents.

This spectacular growth has historically been driven by regulations and social demands. In industrialized countries, the first national laws dealing with air and water pollution, noise reduction and soil protection (for example, measures such as the Clean Air Act, the Clean Water Act, the Noise Control Act and the CERCLA - Comprehensive Environmental Response, Compensation and Liability Act, in the United States) were indeed adopted three or four decades ago. Since governments were at that time unable to provide the needed abatement means, it was up to the private sector to make them.

This, however, does not explain why some specialized firms, not the targeted polluters, would increasingly take charge. We argue below that the emergence of the eco-industry actually verifies an old and well-known prediction made by Adam Smith in The Wealth of Nations, that "the division of labor is limited by the extent of the market." According to this statement, the combination of sustained economic growth (hence the general expansion of markets) and more stringent environmental demands had to lead polluting firms to outsource the production and delivery of abatement goods and services.

Once activated, this division of labor sets a suitable landscape to continuously create value. For polluters and society, first of all, through scale economies, incentives to innovate and the 
development of expertise that will make the control of polluting emissions more effective and less costly. For the eco-industry itself, also, by giving it the opportunity to capture part of the benefits from having a cleaner environment. We show below, moreover, that this Smithian logic tends to be supplemented nowadays by a spreading service logic. This suggests that polluters and their cleantech suppliers could co-create additional value by jointly seeking and implementing augmented offerings which enhance their respective competitiveness. Many obstacles to making this outcome the rule rather than the exception still remain, however. Lifting them will require revising certain public policies and changing several managerial mindsets and practices.

In what follows, the next section gives a short overview of the eco-industry, its history, scope, current situation and projected development. On this basis, section 3 exposes the Smithian and service logics that now lie beneath exchanges between polluting entities (firms, government bodies or communities) and their cleantech suppliers. Section 4 next highlights some current barriers to co-creating value and makes policy recommendations. Section 5 concludes the paper.

\section{The eco-industry - an overview}

In a report to the U.S. Department of Commerce in 1998, David Berg et al. (1998, p. 7) observed at that time that: "The domestic industry that provides environmental products and services is one of the least understood sectors within American industry, despite its size and economic importance.” Things might currently be changing. Several industrial syndicates and trade associations have come into existence, which closely monitor their members' activities, publish forecasts and make recommendations to entrepreneurs and policy makers. Public and private organizations gather more and more precise data on eco-activities, and seek explicitly to 
come up with consensual definitions and classifications that will allow collecting comparable statistics. $^{2}$ This section will now sum up this work, after considering some central historical facts.

\subsection{A short history $^{3}$}

Environmental activities, such as water supply and waste disposal, cleanup and reuse, are probably as old as the advent of the first human settlements, 12000 years ago. Back in the classical period, Ancient Rome also had sophisticated water and sewer systems. But the habit of outsourcing environmental goods and services (EGS) delivery to private parties truly began with the second industrial revolution, at the end of the 19th century. In response to dreadful living conditions and recurrent epidemics in their overcrowded growing cities, public authorities in Europe and North America would then often turn to public-private partnerships for the largescale management of trash and wastewater.

In Europe, most large cities had implemented regular garbage collection by the end of the 1890s. Permission to recover domestic waste was frequently granted to some farming associations that would use it as compost. Two decades later, as farmers switched to chemical fertilizers, local communities resorted regularly to hiring some of the newly constituted truck companies, which would then burn collected litter in the first existing incinerators or in open landfills. Municipal garbage collection and treatment finally came to be privatized to a large extent, although the degree of private firm participation still varies across activities and countries (see Table 1).

\footnotetext{
${ }^{2}$ Surprisingly, though, the academic literature has so far taken little notice of the eco-industry. To our knowledge, only a handful of research papers refer to it explicitly. This might contribute to the framing problems and other barriers to value co-creation which are discussed in section 4.

3 This historical account draws without restraints from Sinclair-Desgagné (2008).
} 
Insert Table 1 about here

In the United States in 1894, Col. George Waring, the newly appointed Streets Cleaning Commissioner of New York City, organized solid waste management around engineering units operations such as street sweeping, refuse collection and transportation, resource recovery and disposal (Louis 2004). This approach was followed nationwide, encouraging the introduction of motorized street sweepers and other innovations. New York City stopped collecting commercial waste in 1957; this forced businesses to contract private companies to take their garbage away. Municipal solid waste across the nation was henceforth largely managed by municipalities which, as in Europe, kept relying to a variable extent on private service providers.

Initial incumbents in the waste management industry had several related business activities. The steady augmentation of the volume and diversity of trash after World War II made this less necessary. The industry is now served by many specialized small and medium-size enterprises, together with a few large firms - such as Waste Management or Veolia - accounting for more than $50 \%$ of the global market. ${ }^{4}$ This peculiar industry structure - a multi-product oligopoly with a competitive fringe - can be attributed to certain factors. First, thousands of municipalities and local communities form a sizeable pool of heterogeneous customers, allowing for sustainable market niches while conferring at the same time a competitive advantage to a few large suppliers able to generate economies of scale in the treatment of waste. Second, the industry lives on specific entry barriers, some raised by organized crime (Carter, 1999), ${ }^{5}$ some due to laws and

\footnotetext{
${ }^{4}$ Market shares may differ across regions of course. After it merged with USA Waste in 1998, Waste Management alone held 25\% of the US overall market. In Europe, medium-size firms such as AGR (Germany), AVR (Austria), and Essent (The Netherlands), which are owned by municipalities, also hold significant ground.

5 Take, for instance, the following excerpt from the July 22, 2005 issue of The Daily Caveat (a newsletter produced by Caveat Research, a Virginia-based private think-tank): "Records in New York and Connecticut show a complex
} 
regulations which often set severe constraints on transportation and disposal (particularly on the number and location of landfills, and with respect to hazardous waste).

Traditional government interventions in waste management were mainly directed at enhancing the supply of goods and services. By contrast, most environmental policies launched in the 1960s and 1970s were instrumental in creating demand for EGS.

Requirements such as the 1975 Waste Framework Directive and Waste Oil Directive in Europe, the 1976 Resource Conservation and Recovery Act in the United States, and the 1972 'bottle bill' in Oregon (to be followed the same year by similar legislations in nine other US states), for instance, clearly raised the need for recycling services. Beforehand, scrap cotton and linen rags had been routinely salvaged and turned into paper throughout the 19th century, wartime shortages had made it worthwhile to sort out and recycle glass bottles and metallic objects, and the aluminum industry had become increasingly keen on recycling since the opening of the first aluminum can recycling plants in Chicago and Cleveland in 1904. But the explicit and lasting commitment of public authorities gave the activity a major impetus. Nowadays, according to the US Environmental Protection Agency, more than 30\% of the 240 million tons of trash produced annually in the United States (including $90 \%$ of car batteries and more than $25 \%$ of plastics) are recycled. Equipments and services are provided on every continent by a thriving but extremely heterogeneous industry. The relative height of entry barriers varies considerably across segments: entry into the collection and sorting of scrap metals, for example, may be restricted by

web of connections among Galante, Milo and Allied Waste, the nation's second-largest garbage handler. Allied, with revenues of $\$ 5.66$ billion in 2004, took over several Westchester companies after an organized-crime monopoly on the industry was broken up by federal indictment in the late 1990s. The biggest player in Westchester's garbage industry at the time was Milo's Suburban Carting, which also owned 40 percent of the stock in Galante's Automated Waste Disposal. In February 1998, Milo was sentenced to three years in prison and paid \$3.2 million in fines and restitution for the part he played in what prosecutors said was a mob-run scheme that used price fixing, violence and intimidation to control Westchester's garbage industry over 35 years.” 
organized crime, while incumbents in the hazardous (notably nuclear) waste recycling business are limited in number due to significant regulatory and technological constraints.

Since the 1960s, the clean air legislations enacted, extended and progressively reinforced in all industrialized countries have also made manufacturers and energy producers look for specific air monitoring and pollution abatement technologies. Specialized providers soon appeared in the newly constituted market branches corresponding to the different types of emissions to be abated (mainly sulfur dioxide, carbon monoxide, and NOx). In the technologically driven competition, some companies like Research Cottrell, Combustion Engineering, and Western Precipitation came out among the overall leaders of US industry until the mid-1980s. Research Cottrell was next acquired by Hamon, a Belgian company founded in the early 1900s which deals with dust emissions control, acid gas removal, and flue gas treatment (in addition to offering products and services for cooling systems, heat exchangers, and chimneys), while Alstom, a French multinational that makes trains, electric turbines, and thermal power plants took over Combustion Engineering, and the American engineering and construction firm McDermott got hold of Western Precipitation. As they expanded further, several segments of the US market became at that time strongholds for other major players, such as Engelhard in catalytic converters, BOC Edwards in industrial exhaust systems, and Marsulex in the treatment of sulfur dioxide and hydrogen sulfide. ${ }^{6}$ Pulled by ever extensive, technical and compound regulations, the industry never ceased meanwhile to harbor a large number of small and medium enterprises providing very specific know-how in narrow niches. ${ }^{7}$

6 In 2006, the German chemical giant BASF bought Engelhard for $\$ 5$ billion, while Edwards parted from the BOC Group which was purchased by the German industrial group Linde for $\$ 14.4$ billion.

7 To know more about the air pollution abatement goods and services industry, the interested reader might look at the September 2005 report by the US International Trade Commission quoted in the bibliography. Another 
Demand for equipment, materials and services to measure, control and abate noise similarly received a definite thrust when the Noise Control Act was passed in the United States in $1972 .^{8}$ Although the program was abandoned at the federal level nine years later, the issue was then tackled by local and state governments, and many European countries, such as the Netherlands in 1979, France in 1985, Spain in 1993, and Denmark in 1994, successively took it on. The private sector responded with hundreds of new dedicated firms serving mainly aircraft, airport, highway, train and car builders, together with appliance manufacturers and the construction industry. ${ }^{9}$ Competition in the activity has remained rather stiff (at least in the United States), despite sometimes significant technical requirements and the continuing presence of trade barriers.

Site remediation is another service that became widely sought-after following the 1980 implementation of the Comprehensive Environmental Response, Compensation and Liability Act (CERCLA) in the United States. Thousands of abandoned sites containing hazardous waste were then identified, and hundreds of them designated for immediate cleanup. Remediation operations were to be supported by taxes or liabilities collected from polluters and put in a special trust fund called 'Superfund.'10 Most industrialized countries endorsed similar programs in succeeding years. From the beginning, contrary to what happened for instance with other EGS linked to waste and noise abatement, contaminated site owners (mainly petroleum and chemical

informative source is the website of the Institute of Clean Air Companies - a nonprofit U.S. association of firms working in the control and monitoring of stationary source air pollution: www.icac.com.

8 The United Kingdom and Japan had already adopted noise control laws in 1960 and 1967, respectively. These measures had a narrower scope and focused mainly on workplace and construction noise.

9 It can actually be difficult to tell apart activities related to noise control and abatement from those involved within client industries (especially the construction industry). However, experts dealing with noise measurement and reduction seem to share a genuine professional culture, as the presence of associations like the National Council of Acoustical Consultants (NCAC) and the Acoustical Society of America (which exists since 1929 and has more than 9,000 members) might illustrate.

10 Over five years, US\$1.6 billion was collected. CERCLA was later amended to increase the amount of the 'Superfund' to US\$8.5 billion (Robinson et al. 2006). 
companies, but also the military and some government bodies) procured all remediation technologies from external suppliers. High market barriers, caused by legal, regulatory and financial uncertainty, long horizons (remediation projects often last more than 20 years), and very specialized training and know-how have subsequently allowed some remediation firms to retain considerable market power (more than $70 \%$ of the site remediation market in Australia, for example, is held by one firm-Thiess Services).

Finally, the creation in 1970 of the Occupational Safety and Health Administration in the United States, and the progressive strengthening of industrial safety regulations in both the United States and Europe (through the 1986 Emergency Planning and Community Right-toKnow Act and the 1982 Seveso I Directive, respectively), launched a sizeable market for environmental testing, monitoring and analytical services, as well as ergonomics, hazards assessment, safety audits, and other professional services. As targeted firms were then focusing more markedly on their respective core competencies, the latter services became increasingly outsourced, fostering the growth of a large environmental consulting and engineering industry.

In 1996, the eco-industry totaled US\$ 452 billion in revenues. Yet, the slower introduction of new environmental measures, and shift away from command-and-control towards market-based regulation, had brought the American EGS industry on the verge of crisis: the sector's growth had come from an average of $11 \%$ throughout the 1970 s and 1980 s to a mere $1 \%$ (Berg et al. 1998). At the same time, Europe’s ever more demanding environmental policy was taking a new stance, less favorable to end-of-pipe abatement which then made up virtually all the earnings of the environment industry. These contrasting situations both resulted in the rapid expansion of process and product design, pollution prevention technologies, cleaner production and resource recovery. Such activities seemed more likely to deliver value to clients increasingly pressured by global competition, tougher stakeholders (notably NGOs), and exacting standards of 
business practice (encoded, for instance, in the 1996 environmental management norm ISO 14000, or the 1995 Environmental Management and Audit Scheme — EMAS), while fitting new requirements (like ‘extended producer responsibility’) based on life-cycle thinking. ${ }^{11}$

The 1990s ultimately saw policy makers pay increasing attention to the EGS industry: not only was it key in determining the quality of urban infrastructure and the cost of complying with environmental regulation, but thousands of jobs and a significant amount of international trade depended directly on it. The only available statistics on the industry, however, had to be purchased from private organizations, such as Environmental Business International (EBI) and The McIlvaine Company, which often produced dissimilar figures because they used different definitions, categories, and methodologies. Time was then ripe for promoting a common position with respect to data collection on environmental goods and services.

\subsection{Definitions}

In a landmark document published in 1999, the OECD and Eurostat jointly define the ecoindustry as follows (OECD/Eurostat 1999, p. 9):

(...) the set of activities which produce goods and services to measure, prevent, limit, minimize or correct environmental damage to water, air, and soil, as well as problems related to waste, noise and eco-systems. These include cleaner technologies, products and services which reduce environmental risk and minimize pollution and resource use.

More recently, in order to get a better grasp at the impact of environmental policies on employment and track the evolution of the so-called 'green' economy, Eurostat (2009) decided to contemplate from now on all 'eco-activities'. These refer to "the production of goods and

\footnotetext{
${ }^{11}$ Extended producer responsibility, also known as 'product stewardship' or 'shared product responsibility,' means that manufacturers must bear from then on some or all of the costs of handling and disposal of their products when those reach the end of their useful life. Policies in this sense are now being adopted in a growing number of countries, in order to slow down the accumulation of trash (particularly of obsolete computers, home appliances and cell phones). For a first economic analysis, see Walls (2003).
} 
services contributing to environmental protection and the management of natural resources.” They can be carried out by private enterprises or public administrations, and include "some auxiliary activities which are not traded but still constitute an expense.” The term 'eco-industry' then refers to "the eco-activities undertaken by an industrial sector."

A taxonomy of the various segments of the eco-industry is provided in Figure 1. Classifications may differ across countries or data sources (see Sinclair-Desgagné 2008, p. 77-80, and EBI 2011, p. 10-17 of chapter 1, for discussions on this issue). Knowing which one holds is of course important before one reads and starts interpreting the available data.

Insert Figure 1 about here

\subsection{Figures and trends}

The eco-industry’s global revenues totaled US\$ 803 billion in 2010. ${ }^{12}$ The United States and the European Union each account for 38\% of this amount, Japan for 17\%, China for 3,2\% and India for 2,5\%. Waste management, followed by potable water and wastewater management, are the most important activities, both in terms of income and employment (they represent $60 \%$ of total revenues and $50 \%$ of jobs).

In general, the eco-industry is also growing faster than the economy as a whole: its overall revenues are projected to reach US\$ 1000 billion in 2015 and up to US\$ 3 trillion in the following decade. This growth now largely depends on infrastructure buildup in emerging

\footnotetext{
12 This specific figure comes from EBI Report 2020 (2011, p. 11 of chapter 1). This section relies on data from this exhaustive report, and from other dependable sources such as Selwyn et Leverett (2006), Ernst \& Young (2006), JEMU (2002), the U.S. International Trade Commission (2005), and Ecotech Québec (2011).
} 
countries, where the pace of industrialization and urbanization makes it more and more necessary to manage solid waste, wastewater, air pollution and soil contamination in a systematic manner. In developed countries, the sector's growth (which is positive as well, but somewhat weaker) is pulled by strong demand for renewable energy, energy efficiency and resource recovery.

Despite the recent economic downturn, employment in eco-activities seems to have done rather well, with an increase of 3\% from 2007 to 2008. The eco-industry now employs more than 1.7 million people and accounts for $2.7 \%$ of GDP in the United States as well as in Europe. According to the $O E C D$, international trade in environmental goods has also grown faster, on average, than trade in all products (14\% versus 6\% on average, between 1990 and 2002).

The above figures put the eco-industry on par with major sectors such as the pharmaceutical, chemical and aerospace industries. By 2020, it should have become third in importance, right after the electronics and automobile sectors. Being a supplier of goods, services and technologies to essentially regulated industries, communities and government bodies confers it a specific dynamics which will now be explored.

\section{The dynamics of the eco-industry}

The preceding section conveys two important stylized facts. First, (although things are now changing) the eco-industry historically delivers what are mostly end-of-pipe remedies to

pollution. Second, the sector's main segments are dominated by a few large firms, which is indicative of the presence of economies of scale and scope. These facts suggest a firsthand explanation for the presence of an eco-industry: it is a natural consequence of the division of labor which, as Adam Smith pointed out early on, both follows and fosters economic development. This section will first examine this rationale a little further. While it justifies the current practice of outsourcing EGS, however, it says nothing on the exchange process that will 
subsequently take place between polluters and their cleantech providers. Yet, it is through this process that value is ultimately created. Drawing from the relationship marketing literature, we will next argue that the provision of EGS now increasingly follows a specific 'service logic'.

\subsection{An ongoing Smithian process}

To see how the Smithian logic of broader division of labor applies here, consider Stigler (1951)'s classical argument which is reproduced in Figure 2. End-of-pipe pollution abatement activities (like solid waste management and recovery, wastewater treatment, and contaminated site remediation) correspond to function $\mathrm{Y}_{1}$ in the picture, since they are subject to economies of scale and display little synergy with other production activities. As the reasoning now goes, polluting firms will prefer to outsource them and benefit thereby from greater expertise and lower costs, as soon as the market is able to support some specialized suppliers. The latter condition was to be achieved over the past decades, thanks to more demanding environmental regulations and sustained economic growth, which altogether gave rise to a critical mass of cleantech customers.

Insert Figure 2 about here

It is worth noticing, moreover, that the largest segments of the eco-industry (notably those pertaining to water and solid waste) are infrastructure components for the economy as a whole and certain industrial sectors (such as mining, power generation, oil and natural gas extraction and refining, pulp and paper production, and chemical manufacturing). Their goods and services are thus somewhat generic, meeting the needs of as many polluters as possible while coping reasonably well with each firm’s specific problems. Bresnahan et Gambardella (1998) consider 
this feature to be an essential (but missing) ingredient of Stigler's argument: vertical specialization must indeed result from a significant increase in the number of client enterprises (which was the case here) rather than a simple rise in firm size (which would have instead lead polluting firms to produce abatement technologies themselves). ${ }^{13}$

Surely, a similar Smithian process did lie behind the emergence of several other sectors, such as freight and machine-tool. Considering the rapid emergence of the eco-industry, other factors must have also played a role in accelerating the process in this case. Over the past 20 years, for instance, following Prahalad and Hamel (1990)'s influential article, a key precept of business strategy, actively taught in business schools and diffused by management consultants, was that firms should center on their core functions. Since pollution management, especially when it is end-of-pipe, hardly qualifies to be such a function, managers were then willing to externalize it whenever they could. The evolution of risk management practices might also have influenced polluters' decision to externalize environmental technologies. One effective way of dealing with uncertainty - in this case, regulatory and scientific uncertainty - is indeed to share part of the burden with a third party, especially if the latter happens to offer some key knowhow and if his interests will thereby be better aligned on those of the client (Blocki 2002).

Whatever factors were involved, the broader division of labor which happened here has brought again significant benefits to society. Thanks to the ensuing expertise, the treatment of certain pollutants has become more effective and less costly. Nowadays, for example, the reduction of odors and emissions of lead and other toxic particles could not do without the particulate scrubbers manufactured and continuously improved by specialized firms. Thanks to the size of the eco-industry, polluting entities can also make EGS providers compete to deliver

\footnotetext{
13 In a recent empirical study, Arora et al. (2009) find that the history of the chemical industry corroborates Bresnahan et Gambardella (1998)’s proposition.
} 
the necessary means to alleviate their ecological footprint. This will keep costs under control while harnessing the diversity and creative potential of cleantech suppliers. Recently, for instance, a large U.S.-based chemical plant that needed to control its volatile organic compounds (VOC) and odor emissions launched a formal bidding process. ${ }^{14}$ After a thorough technical evaluation of the received proposals, it selected a consulting engineering firm and had a customized catalytic oxidization system installed. Not only did it benefit from the ongoing destruction of VOCs and odors, in compliance with regulations and corporate environmental objectives, but it also kept operation and maintenance costs at a minimum.

Environmental footprints are thus now increasingly and more effectively dealt with through Business-to-Business (B2B) interactions. The precise relationship that takes place between polluters and their cleantech suppliers remains to be looked at, however. For, it will largely determine the value that the parties are able to co-create.

\subsection{Polluters and abaters - an impending relational logic}

When the eco-industry's growth in the U.S. almost stalled in the 1990s, some trade associations and consultants recommended working at also preventing polluting emissions and recovering potentially valuable resources instead of just delivering end-of-pipe remedies. ${ }^{15}$ This approach has gained ground in the largest segments of the eco-industry, as the recent report by Environmental Business International (EBI Report 2020, p. 34 of chapter 1) confirms:

Pollution control, waste management and cleanup driven by regulation still represent the majority of revenues in the environmental industry. However, customer demand is replacing these services with pollution prevention and resource recovery investments not wholly dependent on regulations. For example, water

\footnotetext{
${ }^{14}$ The examples cited thereafter are extracted from case studies conducted by the Institute of Clean Air Companies (ICAC), which are available at the website www.icac.com.

${ }^{15}$ See Diener et al. (2000), Sinclair-Desgagné (2008), and EBI Report 2020 (2011, p. 32-34 of chapter 1).
} 
treatment equipment for discharge is losing market share to water treatment and purification equipment for reuse. Expenditures on waste management equipment manufactured for containment, collection and transportation of solid waste for efficient disposal are increasingly being replaced by investments in equipment for sorting, processing and baling materials for recovery. Waste management services are focusing on recovery, and companies are generating profits from both services rendered and sale of recovered materials. Demand for compliance-oriented consulting is drying up, while demand for strategic environmental management and pollution prevention goes unmet.

Ultimately, this would lead cleantech suppliers to reassess their customers' whole operations and seek ways to enhance their competitiveness. By offering thereafter what the marketing literature calls 'augmented products' that support their clients in the competitive game, EGS suppliers will make them prosper and thus set sustainable conditions for their own expansion.

This optimistic scenario seems to have materialized in some instances, as the following examples (taken this time from the air pollution control segment) illustrate:

- Example \#1: A commercial bakery in California, Gold Coast Baking of Santa Ana, wanted an emission abatement system that would make its new production line comply with VOC emission regulations. The company then asked its abatement supplier to build a catalytic oxidizer as an integral component of the new bakery oven. The unique design - incorporated as part of the operation process, not as an end-of-pipe system - resulted in substantial time and money savings. For instance, making the heat circulate into the oven eliminated the need for an additional heat exchanger and lowered fuel consumption by $25 \%$.

- Example \#2: Engineers at a major manufacturing plant in California needed to replace a faulty wet venturi scrubber operating on a waste-wood-fueled boiler. They wanted a system that would drastically lower flyash output, operate efficiently on the variable fuel, and resist fires. This system had to be engineered, fabricated and installed within eight months. The company looked at various ways it could clean the stack emissions generated by its fixed- 
grate stoker boiler, including fabric filters and dry electrostatic precipitators (ESP). A pilot study conducted on site by a control technology supplier, however, convinced the manufacturer that a wet ESP would meet their requirements. Thanks to the acquired information, the supplier then designed, engineered, and installed an air pollution control system that is keeping emissions well below current regulatory thresholds. The company will thereby maintain a competitive edge over other manufacturers as regulation tightens.

- Example \#3: A manufacturing company selling an array of flexible packaging to customers across the U.S. needed to control its Volatile Organic Components (VOC) emissions and treat a wide range of solvents (its plant was located in a residential section of town with a hospital across the street). Its 15-year-old carbon-bed recovery system required a lot of maintenance work and consumed a large amount of fuel. The system also yielded unrecyclable solvents that resulted in significant monthly disposal fees. In addition, the restricted solvent diet that the system could handle was limiting manufacturing flexibility. To address the problem, a regenerative thermal oxidizer (RTO) was built offsite and trucked to the packaging facility in close collaboration with engineers from an industrial equipment installation firm. Stack testing of the installed oxidizer produced an actual destruction efficiency of $98.9 \%$ - more than enough to satisfy the regulatory agency. Compared to the old solvent recovery system, the new system eliminated disposal fees and brought important savings in operating costs, with fuel consumption reduced by $80 \%$. The RTO also eliminated the need for 9,000 pounds of water previously used for daily steam downs. Finally, the plant has been able to put the people in charge of the old solvent recovery system maintenance back into value-adding activities. By considering its cleantech supplier a partner rather than 
some arm's-length dealer, this company was able to convert environmental compliance into a process of value creation.

One may infer from these examples that collaborating more closely with - and giving more leeway to - a cleantech provider will yield additional value to polluters. More fundamentally, these cases show that the exchange process taking place between polluters and their EGS suppliers has a determinant impact on value creation.

One research stream that makes the exchange process between buyers and sellers its core subject is relationship marketing. This field, however, has so far paid little attention to the ecoindustry. ${ }^{16}$ To start filling this gap, let us briefly lay out some theoretical background on what is relationship marketing and what are the key insights that can help understand better (and to some extent anticipate) how polluters and their cleantech providers can jointly create value while mitigating environmental footprints.

Three main themes of relationship marketing shall draw our attention here: (i) the nature of exchange along the transactional-relational continuum, and the parties' preferences for a specific exchange mode; (ii) the notion of value, and value co-creation between buyers and sellers; (iii) the multiple stakeholders involved in business exchange and their respective value perceptions.

(i) The idea that business exchanges can take any form in a continuum between two polar modes appeared some 20 years ago (see, e.g., Dwyer, Schurr et al. 1987; Gummesson 1987; Anderson and Narus 1991). On the one hand, business exchanges can be short-term episodes with no commitment, cooperation or trust between parties - an exchange mode referred to as transactional exchange; on the other hand, exchanges can give rise to sustained interactions

\footnotetext{
${ }^{16}$ Relationship marketing has developed over the past 20 years from a wealth of trans-disciplinary research centering notably on strategic alliances, clusters and industrial networks, as well as supply chain management and total quality management (see, e.g.., Godson 2009 and Egan 2011).
} 
over time, with lasting commitments and collaboration between trade actors - something called relational exchange (e.g., Sheth and Shah 2003). As these definitions suggest, the degrees of trust and commitment between actors are central to identifying the nature of exchange along the continuum. Formalized by Morgan and Hunt (1994), the trust-commitment theory predicts that companies sharing high levels of trust and commitment will tend to trade in a relational exchange mode.

Over the last two decades, researchers have investigated both kinds of exchange modes, as well as combinations of them which they named 'plural marketing practices' (Pels, Coviello et al. 2000; Coviello, Brodie et al. 2002; Brodie, Coviello et al. 2008). While relational exchange is widely seen as a source of competitive advantage, superior financial performance, higher customer satisfaction, upgraded organizational learning, lower uncertainty, increased innovation, and superior value for the exchanging parties (Ravald and Grönroos 1996; Walter, Ritter et al. 2001; Hunt, Arnett et al. 2006), companies overall have not switched massively to a relational mode of exchange and transactional exchange continues to flourish. Recently, Lefaix-Durand and Kozak (2009) actually found in several case studies that both transactional and relational exchange modes can coexist within the same industry and for the same products. They conclude that managing both kinds of exchange mode effectively is key to having a successful business.

Attempts to explain companies' preferences for one exchange mode over the other have mainly focused on contextual factors such as the type of offerings (goods vs. services), the degree of specificity and nature of purchases (commodities vs. value-added or highly specific offerings), industry structure (fragmented vs. consolidated), market types (business-to-consumer vs. business-to-business), the decision-making culture and structure (e.g., tolerant vs. averse to risk), transaction costs and asset specificity (low vs. high), and the stage in the exchange life 
cycle (initiation vs. maintenance, or acquisition vs. retention). ${ }^{17}$ Roughly, a transactional mode of exchange would prevail between companies with low investments in specific assets and a customer-acquisition logic, decision-making cultures that display a relatively high tolerance to risk, and which trade commodity goods in fragmented consumer markets. Conversely, a relational mode of exchange was observed between companies with highly specific investments, a rather risk-averse corporate culture and a customer retention/loyalty development logic, which trade value-added products or services in consolidated markets.

As far as the eco-industry is concerned, these findings might explain why firms in certain segments, such as waste management, have so far operated mostly in a transactional manner, while those in areas such as energy efficiency seem more prone to adopt a relational approach, and those dealing with air pollution or water and soil decontamination work under both modes of exchange. But they hardly account for the current push in all segments of the eco-industry towards relational approaches to EGS provision. As we brought up in the introduction to this subsection and now depict in Figure 3, this trend started in the 1990s when the pressure to reduce environmental footprints slowed down; it is now on the rise as demand for a cleaner, more sustainable, economy picks up steam. Additional explanations are needed in order to get a full grasp at this particular feature of EGS outsourcing.

Insert Figure 3 about here

\footnotetext{
${ }^{17}$ See Porter (1985, 1998), Grönroos (1991), Sharma and Pillai (2003), Sheth and Shah (2003), and Eggert, Ulaga et al. (2006).
} 
(ii) One recent way to address companies' preferences for a specific mode of exchange is to consider value, not only as an outcome - as it is usually seen - but also as an antecedent of exchange (e.g., Geiger et al. 2012). ${ }^{18}$ When a buyer and a seller estimate a deal or a partner to be 'valuable' (for whatever motives), a relational approach is most likely to be preferred to a transactional one, regardless of the contextual factors that surround the exchange (i.e., the type of industry, market, organization, and offering, or the current stage of the relationship). This has implications for the study of exchange between buyers and sellers of clean technologies.

Right now, firms are facing increasing public and private pressure to develop strategies that take environmental concerns into account (e.g., Cerin and Karlson 2002). However, these concerns and their translation into tighter environmental policy are still widely associated with additional costs and limitations on financial performance. As recent developments in relationship marketing suggest, the more polluting firms will instead see value creation in going beyond mere compliance to environmental regulations, the more likely they will adopt a relational mode of exchange with their cleantech providers. On their part, the latter must become aware of the collaboration, communication, risk taking, trust and commitment that a relational approach to business exchange requires, and of the benefits this process entails.

\footnotetext{
18 Value is a core concept in relationship marketing, where it is viewed as the overarching objective to the development of close and long-term relationships with selected business partners (Nevin 1995). Although the notion of value is challenging to define (Blois 2004), areas of consensus among researchers include the following (Woodruff 1997): value is linked to the use of some product; value is perceived by buyers rather than objectively determined by a seller; and value involves a trade-off between what the buyer receives (the benefits related to the offering) and what the buyer gives up to acquire and use the product (the sacrifices or costs related to the offering). From the perspective of a corporate buyer, value has been defined as "the perceived worth in monetary terms of the economic, technical, service, and social benefits received by a customer firm in exchange for the price paid for a product offering, taking into consideration the available alternative suppliers' offerings and prices" (Anderson and Narus 1998). From the perspective of a seller, value has been regarded as "the perceived tradeoff between multiple benefits and sacrifices gained through a customer relationship by key decision makers in the supplier's organization" (Walter, Ritter et al. 2001). The study of value involves not only the creation, production, and generation of value but also its capture, extraction, migration, exchange, distribution, and sharing between buyers and sellers (e.g., Bowman and Ambrosini 2000; Lepak, Smith et al. 2007). In a B2B context, value creation refers to "the process by which competitive abilities [of partners] are enhanced by being in the relationship” (Wilson 1995).
} 
(iii) In the 1990s, finally, acknowledging the complexity of business exchanges, relationship marketing shifted somewhat from a company-level to a network-level analysis of value creation. The field now studies the nature of exchange and value processes, not only within buyer-seller dyads, but within whole business networks. The latter are regarded as sets of connected firms or relationships between firms (e.g., Anderson, Håkansson et al. 1994). These networks, also referred to as extended supply chains, can include the customers' customers, the suppliers’ suppliers, and competitors (Ravald and Grönroos 1996; Payne and Holt 2001).

To see the relevance of this viewpoint in our context, take for instance a large manufacturer on the brink of renewing its pollution control equipments. Learning more about an upcoming regulation would likely influence its purchasing decision. ${ }^{19}$ This might happen through an engineer from a cleantech supplier who happens to be on the advisory board of the concerned governmental agency. Such informal communication - a characteristic of relational exchange - could save the manufacturer lots of time and money if the wrong equipments were about to be chosen.

Undoubtedly, information exchange, especially if it is on strategic matters, is a core driver of value. Identifying the relevant sources of information and understanding how information flows between buyers and sellers is thus essential, but it is only possible by considering the larger network in which buyers and sellers are embedded. This is particularly important for pollution mitigation, since the decision-making process that will support the use of some environmental remedies is likely to be driven by stakeholders other than the buyer itself. Figure 4 gives a simplified map of these stakeholders and their main role in the reduction of

\footnotetext{
19 For additional illustrations of this assertion (which explains why business-government relationships is an important chapter of environmental strategy), see Porter and van der Linde (1995), Sinclair-Desgagné (2005), and EBI Report 2020 (2011, p. 48 of chapter 1).
} 
environmental footprints. The solid arrows stand for commercial linkages between sellers and buyers, while the dotted lines represent non-commercial connections between stakeholders.

For the sake of clarity, this figure only includes corporate buyers (i.e., polluting manufacturers and firms in general). Other types of buyers - namely public buyers like cities, government agencies or the army - are of course embedded in relatively similar networks. Moreover, cleantech providers appear here as a single actor, but in reality different businesses might collaborate to reduce environmental impacts (for instance, remediation firms often rely on other EGS providers for site characterization, monitoring instruments, and reduction of their own environmental footprint). A more complete map would also comprise trade and industrial associations, business competitors, financial institutions, environmental funds, and so on.

Insert Figure 4 about here

This completes our representation of the ongoing dynamics in the provision of environmental goods and services. This dynamics combines the Smithian logic of broader and broader division of labor with a growing trend towards relational exchanges (as opposed to pure transactional ones) between polluters and their cleantech suppliers. The latter suggests that cleantech procurement might increasingly become a locus of value co-creation. This forecast, however, must currently be qualified due to a number of barriers we shall now highlight.

\section{Some specific barriers to value co-creation}

A distinctive feature of the eco-industry is its historical dependence upon environmental regulation and public policies. These indisputably have a critical impact on the processes and 
outcomes of EGS outsourcing, hence on the modes of exchange that polluters and cleantech suppliers will adopt and the value they will then co-create. Accordingly, this section will first discuss how government interventions could better encourage value-enhancing interactions between polluting entities and their suppliers of EGS. Section 3 also brought up that the parties' respective preferences, viewpoints and capabilities matter in B2B relationships. We will then consider next the hurdles that real or perceived business risks, diverging roles, and contract framing may pose to value co-creation.

\subsection{Un-coordinated public policies}

Since the production of environmental goods and services increasingly weighs on employment and international trade, several governments - notably in the United States, Canada, Germany, the United Kingdom, France, China and India - and the European Union (after adopting the so-called Lisbon strategy) are now actively and openly promoting their eco-industry. These actions give emphasis to public funding of environmental R\&D, the economic intelligence necessary to identify and enter foreign markets, the design of public procurement, the advent of business alliances and partnerships between private firms and public research institutes, and the availability of venture capital. They thus certainly give an additional thrust to the ongoing Smithian process of broader division of labor. Yet, they might not yield the expected outcome without better coordinating with other policies.

First of all, environmental policy, which relies on mandatory technical standards, taxes, quotas, tradable permits and voluntary agreements, should be revised according to its impact on the structure of the eco-industry. Environmental policy largely determines the size of the market for environmental remedies. More importantly, perhaps, it also influences the price-elasticity of 
demand for abatement goods and services. ${ }^{20}$ A polluting firm subject to a technical standard, for instance, will be less sensitive to the price charged by its abatement suppliers than if it can choose between paying some extra pollution taxes versus further lowering its emissions by acquiring certain technologies. It follows that an oligopolistic eco-industry will usually charge higher markups under the former policy than under the latter. ${ }^{21}$ The choice and design of environmental policy instruments can thus affect significantly the prices of environmental goods and services, hence the resulting profits of abatement suppliers. On the one hand, prices which are too high will hamper polluters’ competitiveness (while possibly making the goals of environmental policy unachievable in the first place); on the other hand, prices which are too low will deter entrepreneurship and innovation in the eco-industry.

Like innovation in general, environmental innovation is also mainly stimulated by public policies that foster competition (Baumol 2002). Competition must be tuned up and managed in such a way that innovation (more than regulation) becomes essential for survival in the ecoindustry. Subsidies and programs inviting new entrants, such as American Recovery and Reinvestment Act of 2009 (ARRA) in the United States, thus go in the right direction and should be pursued, if not incremented. ${ }^{22}$ At the same time, competition policy must apply vigorously to the eco-industry, considering the increasing market concentration in certain segments (in the solid

\footnotetext{
20 This observation was first made by David and Sinclair-Desgagné (2005). The economic literature that subsequently examined its ramifications for environmental policy is covered in Sinclair-Desgagné (2008).

21 This conclusion has received empirical support. For example, Lange et Bellas (2005) found that the price of scrubbers to control sulfur dioxide emissions dropped drastically in the United States, following the reform of the Clean Air Act which put forward market instruments (in this case, tradable permits) in replacement of mandatory technical standards. The data reveal that this drop is not due to a sudden burst of innovativeness nor to an increase in competition (for market concentration rather increased) within the eco-industry. The remaining explanation is that the price-elasticity of demand for scrubbers went up.

22 According to Environmental Business International, the eco-industry segments most likely to benefit from the ARRA are the renewable energy, energy efficiency and green construction ones (see EBI Report 2020, p. 52 of chapter 1 ).
} 
waste treatment and air pollution abatement ones, notably). ${ }^{23}$ Finally, regulatory uncertainty should be lowered as much as possible: by increasing the initial capital necessary for a firm to self-protect against future rules, it certainly generates significant entry barriers for new entrepreneurs.

Rarely mentioned but as important for the expansion of eco-activities would finally be governmental actions aiming at harmonizing definitions and international classifications, and countering corruption which often plagues the construction sector and solid waste management in certain countries. The former will allow lifting several barriers to trade in environmental goods and services, thereby increasing competition within the eco-industry and enlarging the market for abatement suppliers. This might further enhance the division of labor (waste management, for instance, relies on the successive interventions of gathering, sorting, treatment and recycling specialists) and generate more economies of scale and scope. ${ }^{24}$ Actions against corruption, on the other hand, will not only benefit the environment by improving compliance with rules and regulations, they will also foster professionalism and expertise in the delivery of environmental goods and services. ${ }^{25}$

All these policies, provided they are properly applied and synchronized, should drive cleantech firms and their customers towards value co-creation. To achieve this goal with greater certainty, however, they must be accompanied by appropriate managerial mindsets and practices.

\footnotetext{
23 David and Sinclair-Desgagné (2010) recently showed that granting subsidies to the eco-industry while taxing polluting emissions can be economically (Pareto) efficient. The role competition policy can play to limit concentration in the eco-industry is analyzed by Canton et al. (2011).

${ }^{24}$ More precise and consensual definitions would also allow to better monitor the eco-industry, which is necessary in order to design and implement successful environmental and industrial policies.

${ }^{25}$ In an article of its February 26 2009 edition ("Talking rubbish - A special report on waste”), The Economist magazine shows how the elimination of corruption in certain regions has indeed had a positive impact on professionalism and innovation in waste management.
} 


\subsection{Perceived risks and vulnerability}

Management research on B2B relationships generally focuses on value creation - and more recently value co-creation - but there is also a dark side to long-term collaborations (see, e.g., Grayson and Ambler 1999; Anderson and Jap 2005).

Scholars in logistics and supply chain management, notably, have pointed out the 'vulnerability' which might occur in relational exchange. With the introduction of extranets, electronic procurement systems and other information technology applications, for instance, security issues related to information sharing have become more and more important in inter-firm relationships. Vulnerability can then emerge from the “(...) dependence on real time connectivity, channel balance of power, strategic integration, information sharing, and investments in technology" (Bowersox et al. 2000). Some a priori beneficial interactions can also turn into damaging ones for the involved parties if governance mechanisms are not appropriate. Organizational learning, for example, can lead to inadvertent and unwanted skills transfer between partners, resulting in the potential dilution of their competitive advantage (Mohr and Sengupta 2002).

All in all, apprehensions about vulnerability in business relationships are mainly influenced by trust and dependence between firms (see, e.g., Svensson 2002 and 2004). Dependence arises naturally over time from repeated interactions (Macneil 1980; Dwyer et al. 1987). It may lead to conflicts as one party grows more confident, exercises power and makes increasingly demanding requests (e.g., Brown et al. 1983; Gaski 1984; Lusch and Brown 1996). This so-called 'hold-up problem' has been widely analyzed in the theory of the firm (see Che and Sákovics 2008, and the references therein). It is generally associated with asymmetric partnerships and non-contractible relationship-specific investments and outcomes (Williamson 1985; Holmstrom and Roberts 
1998), two features inherent as well to the polluter and cleantech supplier dyad. The Smithian division of labor entails indeed that a polluter's and its EGS supplier's respective expertise and core competences will likely lie in very different areas. Meanwhile, a polluting entity’s reputation of care and diligence - which can translate into significant social benefits and reductions in costly regulatory controls - might end up relying crucially on the services of a particular cleantech firm. The expected risk associated with this situation can deter relational exchange at the onset. Generic solutions include 'hostages' (Williamson 1979) and legal remedies (Edlin and Reichelstein 1996; Rogerson 1992). Whether and how these can be put at work in EGS outsourcing remains to be seen.

\subsection{Diverging roles and multilevel complexity}

Other impediments to the development of a relational exchange orientation and value cocreation lie in the divergence of motivations between buyers and sellers and in discrepancies in their respective decision-making structures and cultures.

To be sure, buyers and suppliers do not engage in developing business relationships for the same reasons and with the same degree of motivation (Geiger et al. 2012). Sellers tend to have stronger interests than buyers in bounding with trade partners; this is probably even truer in EGS outsourcing, considering that the purchase of clean technologies is often perceived as a constraint by polluting firms. First, a focal relationship in EGS provision locates at the end of a supplier's value chain, whereas it stands at the outset of a buyer's one (Porter 1985). Its impact is thus obvious to supplying companies, because they immediately see it through sales and profits, but it can be elusive to buying entities which might impute it to purchasing activities, inbound logistics, manufacturing and assembly, or research and development (Geiger et al. 2012). In addition, suppliers usually try to stabilize their customer base through strong binding because customer 
retention is less costly than customer acquisition. On the contrary, buyers often try to avoid dependence on a particular supplier, even if a new trend is set to reduce the supply base in order to save costs (Liu et al. 2005). This behavior is likely to hold as well in the procurement of clean technologies.

Decision-making to sell and purchase EGS can also be quite different from one company to another. As Sheth and Shah (2003, p. 629) put it:

In some companies, procurement related decision making resides within a multifunctional group or committee, and in other companies, individual departments or employees hold sole responsibility for supplier choice. (...) We postulate that in organizations where decision making regarding key input resources is made by a crossfunctional group or where an entire unit of decision-makers is involved, the preference for a relational orientation will be prevalent.

The more clean technologies are considered key 'inputs' and the more they become integrated in the upstream processes of polluting firms, the more relational exchanges are likely to develop. However, the consequent need for increased coordination and collaboration between buyer and supplier firms might constitute by itself a strong deterrent to the upstream adoption of sophisticated clean technologies. Decision making becomes more diffused and takes more time as multiple stakeholders get involved (Sheth and Shah 2003). This represents an added complexity that decision-makers contemplating the acquisition of clean technologies might be neither ready nor willing to manage.

\subsection{Inappropriate framing}

The argument that contract framing has an impact on value creation was recently made by Weber and Mayer (2011). They use the terms 'prevention frame' and 'promotion frame' to denote 'minimalist' and 'maximalist' frames respectively. In their own words (p. 54):

A prevention frame leads to an interpretation of a goal as minimal (something that must be met), which induces high-intensity negative emotions if the goal is not achieved and low-intensity positive emotions if the goal is met. (...) Conversely, 
under a promotion frame, parties view the same goal as maximal (something that would be ideal if reached). If a maximal goal is missed, low-intensity negative emotions are experienced, whereas if a maximal goal is reached, high-intensity positive emotions are induced. Thus, in an effort to reach the maximal goal and avoid sins of omission, parties display more flexible and creative behavior.

Clearly, promotion frames agree better with the impending relational logic of EGS outsourcing than prevention ones. Such frames are currently not taking hold across polluting entities, however. This might be attributed, at least partially, to the current stage of management research and training. Consider, for instance, the celebrated 'Porter Hypothesis', which states that complying with more demanding but well-designed environmental regulation can enhance a polluter's competiveness (Porter and van der Lind 1995). The underlying rationale is that such regulation will force polluting entities to seek innovations which are both privately and socially profitable. More than twenty years of research in management and economics (see Ambec and Lanoie 2008 for a good survey) have brought a wealth of cases in support of this assertion. Yet, the precise processes through which innovation takes place remain obscure. In particular, the literature is startlingly silent about the widespread practice of EGS outsourcing and how to fruitfully manage the resulting interactions between polluters and their cleantech suppliers.

\section{Concluding remarks}

This paper shed light on the widely overlooked interface between polluting entities and the suppliers of goods, services and technologies which can help alleviate their environmental footprint. Investigating this interface, we argued that it arose through a standard process of Smithian division of labor, and was currently subject to an incipient relational exchange logic through which polluters and abaters might end up co-creating substantial value. Before this outcome is realized, however, a number of obstacles need be lifted: inadapted and un-coordinated 
public policies, perceived vulnerability and holdup threats, divergent decision-making cultures and structures, and wrong management frames.

These current obstacles suggest many valuable avenues for future research. The design of instruments for environmental regulation (taxes, pollution permits, voluntary approaches, etc.) is only starting to take into account its effect on the polluter-abater dyad. One should also investigate the organizational traits that render relational exchange between polluters and cleantech suppliers plausible and desirable, and how to make these occur. As we pointed out, the relationship marketing literature is still evolving on this issue. EGS outsourcing undoubtedly constitutes a fertile ground for testing emerging ideas in this area, but also (and perhaps more importantly) for generating new ones. 
Table 1. Percentage of the total weight of domestic waste managed by private firms (Davies 2003)

\begin{tabular}{|lcc|}
\hline Country & Collection & Treatment \\
Spain & 75 & 90 \\
Germany & 60 & 90 \\
United Kingdom & 35 & 80 \\
France & 50 & 70 \\
Holland & 30 & 40 \\
Italy & 40 & 25 \\
Sweden & 45 & 10 \\
Finland & 100 & 5 \\
\hline
\end{tabular}

Figure 1: The eco-industry or cleantech sector's market segments (Adapted from Ecotech Québec 2011)

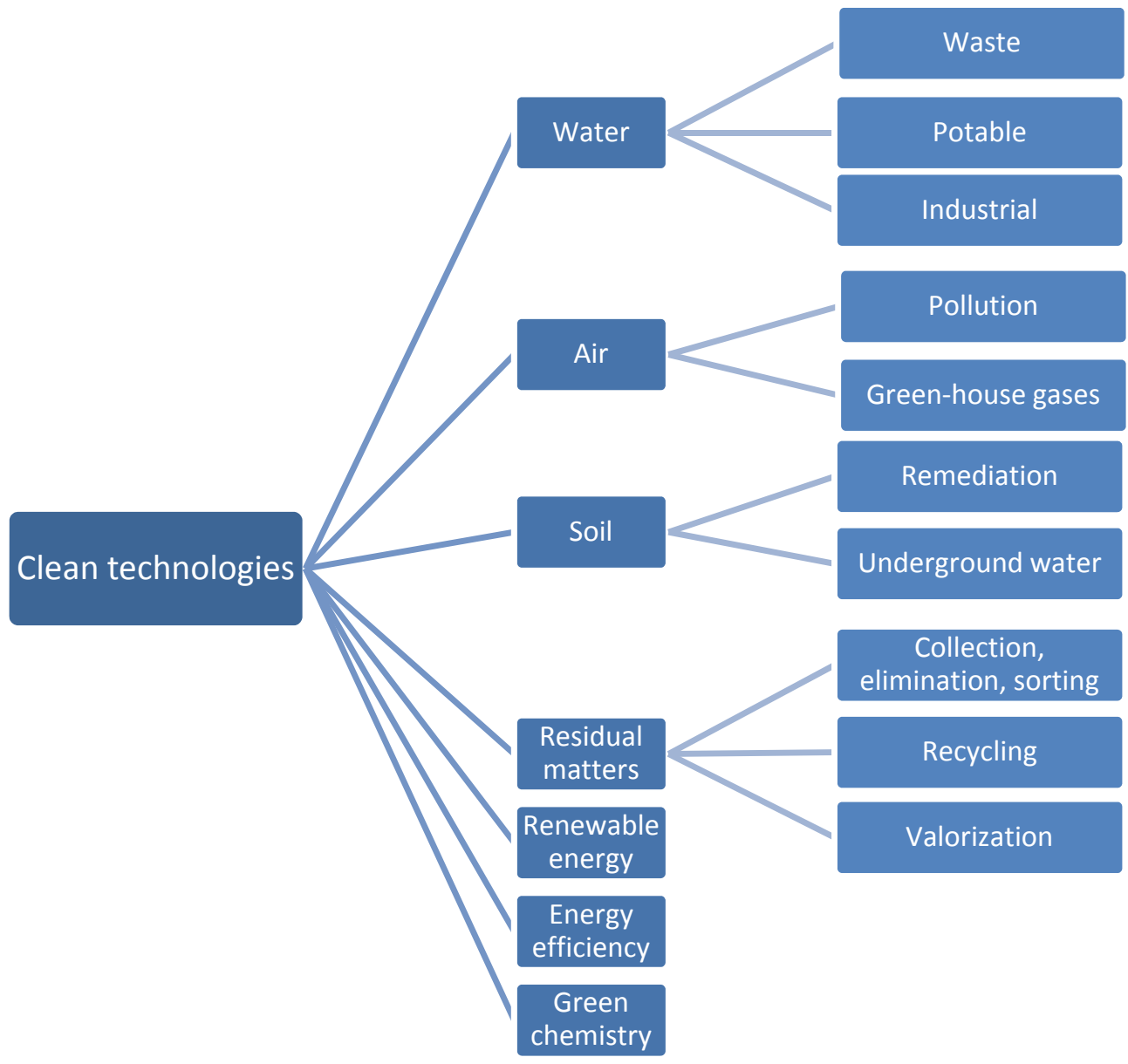


Figure 2: George Stigler (1951, p. 187-188)’s demonstration of Adam Smith's assertion - "The division of labor is limited by the extent of the market."

"That is, we partition the firm, not among the markets in which it buys its inputs but among the functions or processes which constitute the scope of its activity. (...) If the cost of each function depends only on the rate of output of that function, we may draw a unique cost curve for it. (...) We should expect to find many different patterns of average cost functions: some falling continuously $\left(\mathrm{Y}_{1}\right)$; some rising continuously $\left(\mathrm{Y}_{2}\right)$; some conventionally $\mathrm{U}$-shaped $\left(\mathrm{Y}_{3}\right) .(\ldots)$ with the expansion of the industry, the magnitude of the function subject to increasing returns may become sufficient to permit a firm to specialize in performing it. The firms will then abandon the process $\left(\mathrm{Y}_{1}\right)$, and a new firm will take it over."

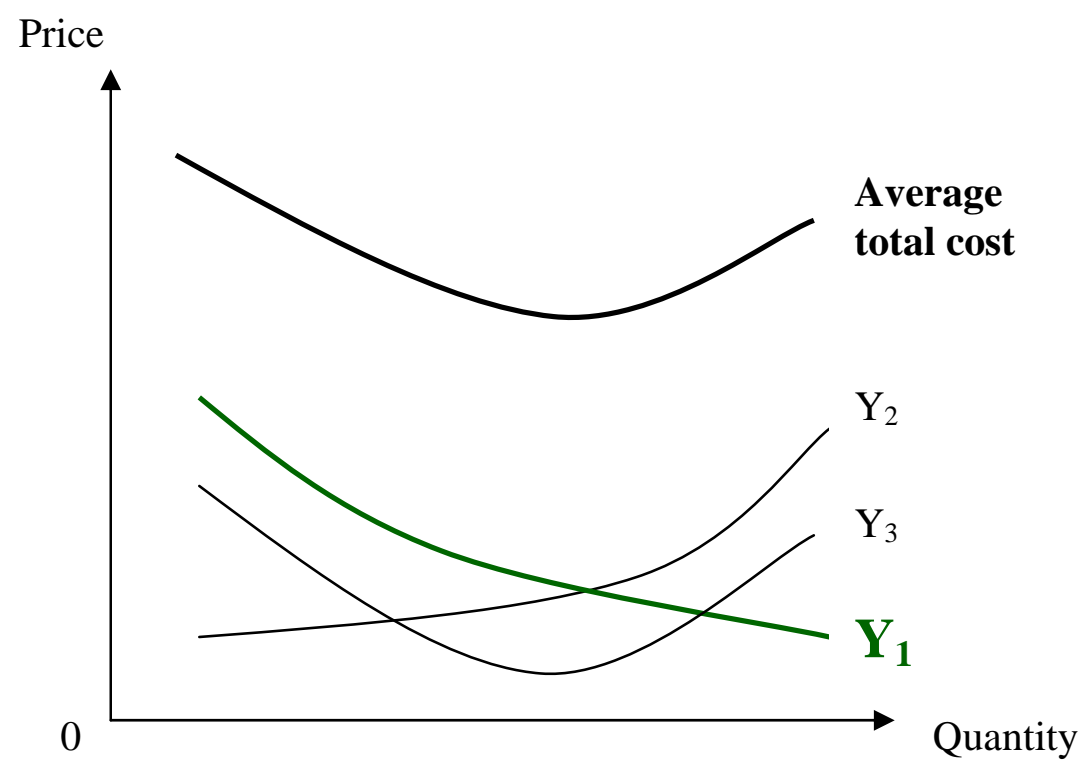


Figure 3: The organization of pollution abatement

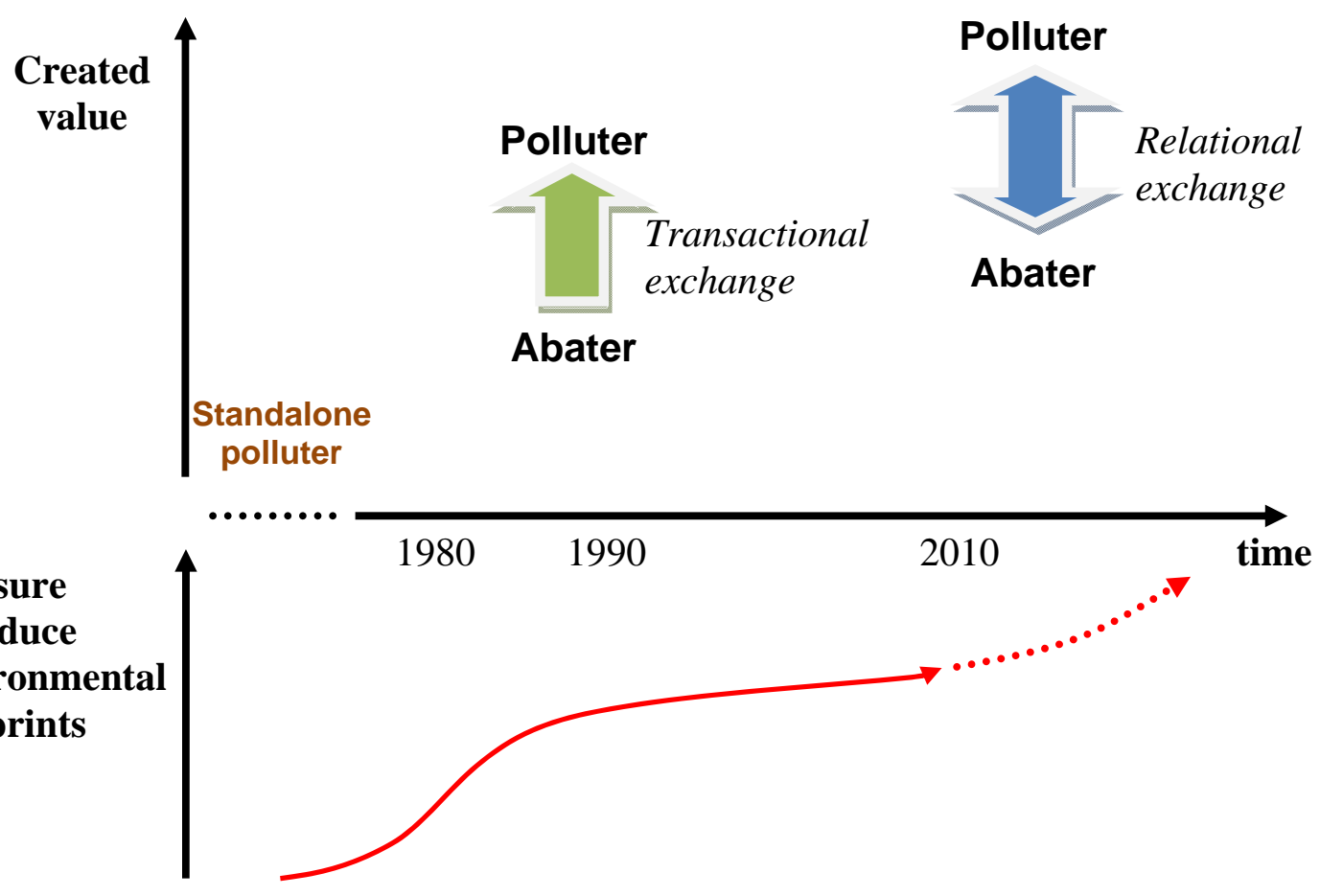

Figure 4: Mapping stakeholders for EGS outsourcing

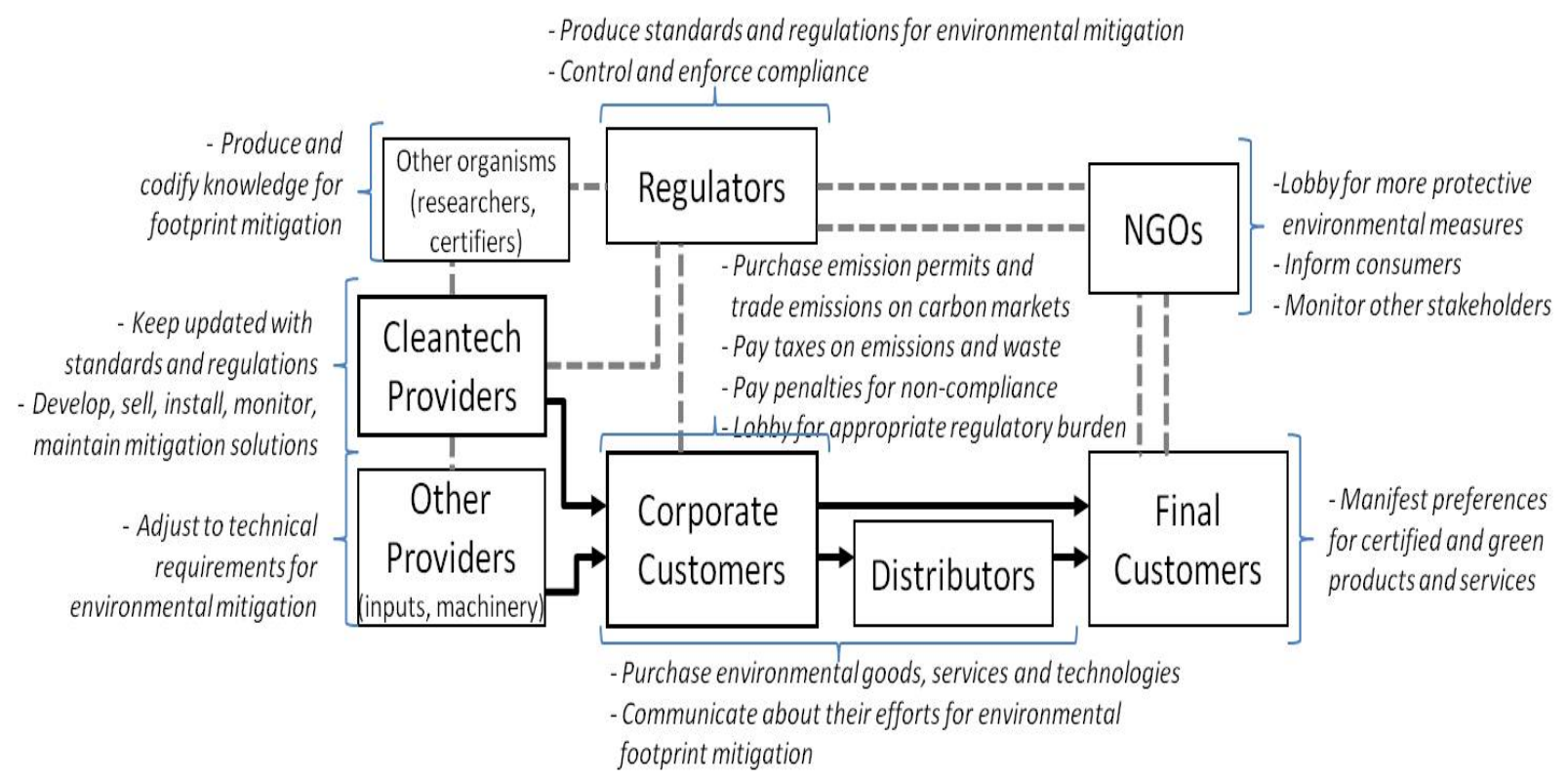

\section{References}


Ambec, Sefan and Paul Lanoie (2008): "Does it pay to be green? A systematic overview," Academy of Management Perspectives , vol. 23, no. 4, p. 45-62

Anderson, E. and S. D. Jap (2005): “The Dark Side of Close Relationships,” MIT Sloan Management Review, vol. 46, no. 3, p. 75

Anderson, J. C., H. Håkansson, et al. (1994): "Dyadic Business Relationships within a Business Network Context,” Journal of Marketing, vol. 58, no. 4, p. 1-15

Anderson, J. C. and J. A. Narus (1998): "Business marketing: Understand what customers value,” Harvard Business Review, vol. 76, no. 6, p. 53

Anderson, J. C. and J. A. Narus (1991): "Partnering as a Focused Market Strategy,” California Management Review, vol. 33, no. 3, p. 95-113

Arora, Ashish, William B. Vogt and Ji Woong Yoon (2009): "Is the division of labor limited by the extent of the market?: evidence from the chemical industry,” Industrial and Corporate Change, vol. 18, no. 5, p. 785-806

Baumol, William J. (2002): The Free Market Innovation Machine, Princeton University Press

Blocki, Stephen W. (2002): “Outsourcing environmental compliance,” Chemical Engineering Progress, October 2002

Berg, David R., Grant Ferrier and Jon Paugh (1998): “The U.S. environmental industry,” US Department of Commerce - Office of Technology Policy

Blois, K. (2004): “Analyzing exchanges through the use of value equations,” The Journal of Business \& Industrial Marketing, vol. 19, no. 4/5, p. 250-257

Bowersox, D. J., D. J. Closs et al. (2000): “Ten mega-trends that will revolutionize supply chain logistics,” Journal of Business Logistics, vol. 21, no. 2, p. 1-14

Bowman, C. and V. Ambrosini (2000): "Value creation versus value capture: Towards a coherent definition of value in strategy,” British Journal of Management, vol. 11, no. 1, p. 1

Brännlund, Runar and Tommy Lundgren (2009): "Environmental policy without costs? A review of the Porter Hypothesis,” International Review of Environmental and Resource Economics, vol. 3, p. 75-117

Bresnahan, Timothy and Alfonso Gambardella (1998): "The division of inventive labor and the extent of the market,” in E. Helpman (éditor), General Purpose Technologies and Economic Growth, MIT Press: Cambridge, MA

Brodie, R. J., N. E. Coviello et al. (2008): “Contemporary Marketing Practices research program: a review of the first decade,” The Journal of Business \& Industrial Marketing, vol. 23, no. 2, p. 84

Brown, J. R., R. F. Lusch, et al. (1983): “Conflict and Power-Dependence Relations in Retailer-Supplier Channels," Journal of Retailing, vol. 59, no. 4, p. 53

Canton, Joan, Maia David and Bernard Sinclair-Desgagné (2012): "Environmental Regulation and Horizontal Mergers in the Eco-Industry," to appear in Strategic Behavior and the Environment

Carter, T. S. (1999): “Ascent of the corporate model in environmental-organized crime,” Crime, Law and Social Change, vol. 31, p. 1-30

Cerin, P. and L. Karlson (2002): “Business incentives for sustainability: a property rights approach,” Ecological Economics, p. 40, vol. 1, p. 13-22 
Che, Yeon-Koo, and József Sákovics (2008): “Hold-up problem,” in The New Palgrave Dictionary of Economics, 2nd Edition

Coviello, N. E., R. J. Brodie et al. (2002): "How firms relate to their markets: An empirical examination of contemporary marketing practices,” Journal of Marketing, vol. 66, no. 3, p. 33-46

Davies, S. (2003): "European waste management: background to a discussion on EWCsa Report for the European Federation of Public Service Unions (EPSU),” Cardiff School of Social Sciences.

David, Maia, Alain-Désiré Nimubona and Bernard Sinclair-Desgagné (2011): "Emission Taxes and the Market for Abatement Goods and Services,” Resources and Energy Economics, vol. 33, no. 1, 179-191

David, Maia and Bernard Sinclair-Desgagné (2010): "Pollution Abatement Subsidies and the Eco-industry," Environmental and Resource Economics, vol. 45, no. 2 (2010), 271-282

David, Maia and Bernard Sinclair-Desgagné (2005): “Environmental regulation and the eco-industry,” Journal of Regulatory Economics, vol. 28, p. 141-155

Diener, Betty J., David Terkla, and Erick Cooke (2000): The Massachussetts Environmental Industry - Facing the Challenges of Maturity, University of Massachussetts Donohue Institute

Dwyer, F. R., P. H. Schurr et al. (1987): "Developing Buyer-Seller Relationships," Journal of Marketing, vol. 51, no. 2, p. $11-27$

Écotech Québec (2011): Working document “Les technologies propres au Québec : étude et étalonnage” presented by consulting group Deloitte during the $3^{\text {rd }}$ Forum on Cleantechnologies organized by Écotech Québec, Longueil, November $24^{\text {th }}, 2011$

Edlin, Aaron and Reichelstein, Stefan (1996): "Holdups, Standard Breach Remedies, and Optimal Investment," American Economic Review, vol. 86, no. 3, p. 478-501

Egan, J. (2011): Relationship Marketing, Pearson Education Limited

Eggert, A., W. Ulaga et al. (2006): "Value creation in the relationship life cycle: A quasi-longitudinal analysis," Industrial Marketing Management, vol. 35, no. 1, p. 20

EBI Report 2020 (2011): The U.S. Environmental Industry \& Global Market, Environmental Business International

Ernst \& Young: Eco-industry, its Size, Employment, Perspectives and Barriers to Growth in an Enlarged EU, European Commission - DG Environment, September 2006

Eurostat (2009): The Environmental Goods and Services Sector - A Data Collection Handbook, Office for Official Publications of the European Communities

Gaski, J. F. (1984): “The Theory of Power and Conflict in Channels of Distribution,” Journal of Marketing, vol. 48, no. 3, p. 9

Geiger, I., Durand, A., Saab S., Kleinaltenkamp, M., Baxter, R., Lee Y.: “The bonding effects of relationship value and switching costs in industrial buyer-seller relationships: An investigation into role differences," Industrial Marketing Management, Forthcoming 2012, in Press http://www.sciencedirect.com/science/article/pii/S0019850111002318

Godson, M. (2009): Relationship Marketing, Oxford University Press

Grayson, K. and T. Ambler (1999): “The dark side of long-term relationships in marketing services,” Journal of Marketing Research, vol. 36, no. 1, p. 132-141 
Grönroos, Christian (2010): “A service perspective on business relationships: The value creation, interaction and marketing interface,” Industrial Marketing Management, vol. 40, no. 2, p. 240-247

Grönroos, Christian (1991): “The Marketing Strategy Continuum: A Marketing Concept for the 1990s," Management Decision, vol. 29, no. 1

Gummesson, E. (1987): “The New Marketing - Developing Long-Term Interactive Relationships.,” Long Range Planning, vol. 20, no. 4, p. 10-20

Holmström, Bengt and John Roberts (1998): “The Boundaries of the Firm Revisited” Journal of Economic Perspectives, vol. 12, no. 4, p. 73-94

Hunt, S. D., D. Arnett et al. (2006): “The explanatory foundations of relationship marketing theory,” Journal of Business \& Industrial Marketing, suppl. Relationship theory and business markets, vol. 21, no. 2, p. 72-87

Joint Environmental Markets Units (JEMU): Global Environmental Markets and the U.K. Environmental Industry, 2002

Lange, Ian and Allen Bellas (2005): "Technological change for sulfur dioxide scrubbers under market-based regulation,” Land Economics, p. 546-556

Lefaix-Durand, Aurélia and Robert Kozak (2010): “Comparing customer and supplier perceptions of value offerings: an exploratory assessment,” Journal of Business Market Management, vol. 4, p. 129-150

Lefaix-Durand, Aurélia and Robert Kozak (2009): "Integrating transactional and relational exchange into the study of Exchange Orientation in customer relationships," Journal of Marketing Management, vol. 25, no. 9/10, p. 1003

Lepak, D. P., K. G. Smith et al. (2007): "Value Creation and Value Capture: A Multilevel Perspective,” The Academy of Management Review, vol. 32, no. 1, p. 180-194

Lindgreen, Adam et Finn Wynstra (2005): "Value in business markets: What do we know? Where are we going?," Industrial Marketing Management, vol. 34, p. 732-748

Louis, G. E. (2004) : “A historical context of municipal solid waste management in the United States,” Waste Management and Research, vol. 22, p. 306-322

Lusch, R. F. and J. R. Brown (1996): “Interdependency, contracting, and relational behavior in marketing channels,” Journal of Marketing, vol. 60, no. 4, p. 19

Macneil, I. (1980): The_New Social Contract, An Inquiry into Modern Contractual Relations, Yale University Press

Mohr, J. J. and S. Sengupta (2002): "Managing the paradox of inter-firm learning: The role of governance mechanisms," The Journal of Business \& Industrial Marketing, vol. 17, no. 4, p. 282-305

Morgan, R. M. and S. D. Hunt (1994): “The Commitment-Trust Theory of Relationship Marketing,” Journal of Marketing, vol. 58, no. 33, p. 20-38

Nevin, J. R. (1995): "Relationship marketing and distribution channels: Exploring fundamental issues," Journal of the Academy of Marketing Science, vol. 23, no. 4, p. 327-334

Nimubona, Alain-Désiré and Bernard Sinclair-Desgagné (2011): "Polluters and Abaters," Annals of Economics and Statistic, vol. 103/104, p. 9-24

OECD/Eurostat (1999): The Environmental Goods and Services Industry - Manual for Data Collection and Analysis, OECD publishing 
Palmatier, Robert W. (2008): “Interfirm relational drivers of customer value,” Journal of Marketing, vol. 72, p. 7689

Payne, A. and S. Holt (2001): "Diagnosing customer value: Integrating the value process and relationship marketing," British Journal of Management, vol. 12, no. 2, p. 159-182

Pels, J., N. E. Coviello et al. (2000): "Integrating transactional and relational marketing exchange: A pluralistic perspective,” Journal of Marketing Theory and Practice, vol. 8, no. (3), p. 11

Porter, Michael E. (1998): “Clusters and the new economics of competition,” Harvard Business Review, vol. 76, no. 6, p. 77-85

Porter, Michael E. and Claus van der Linde (1995): "Toward a new conception of the environment competitiveness relationship,” Journal of Economic Perspectives, vol. 9, no. 4, p. 97-118

Porter, Michael E. (1985): Competitive Advantage: Creating and Sustaining Superior Performance,

Prahalad, C. K. and R. Venkat (2004): “Co-creation experiences: The next practice in value creation,” Journal of Interactive Marketing, vol. 18, no. 3, p. 5

Prahalad, C. K. and Gary Hamel (1990): “The core competencies of the corporation,” Harvard Business Review, p. 79-91

Ravald, A. and C. Grönroos (1996): “The value concept and relationship marketing,” European Journal of Marketing, vol. 30, no. 2, p. 19-30

Robinson, P. R., E. I. Shaheen, and E. I. Sahheen (2006) : “Environmental pollution control,” in Practical Advances in Petroleum Processing (C. S. Hsu and P. R. Robinson, eds.), Springer

Rogerson, William (1992): "Contractual Solutions to the Hold-Up Problem," Review of Economic Studies, vol. 59, no. 4, p. 774-94

Selwyn, Jonathan and Bill Leverett (2006): "Emerging markets in the environmental sector," UK Centre for Economic and Environmental Development (UK CEED) report to Department of Trade and Industry

Sharma, A. and K. Pillai (2003): "The Impact of Transactional and Relational Strategies in Business Markets: An Agenda for Inquiry,” Industrial Marketing Management, vol. 32, p. 623-626

Sheth, J. N. and R. H. Shah (2003). "Till Death Do Us Part...But Not Always: Seven Antecedents to a Customer's Relational Preference in Buyer-Seller Exchanges." Industrial Marketing Management 32(8): 627-631.

Sinclair-Desgagné, Bernard (2008): “The environmental goods and services industry,” International Review of Environmental and Resources Economics, vol. 2, p. 69-99

Sinclair-Desgagné, Bernard (2005): “Introduction,” in Corporate Strategies for Managing Environmental Risks, Vol. XX of The International Library of Environmental Economics and Policy, Ashgate Publishing

Stigler, George J. (1951): “The division of labor is limited by the extent of the market," Journal of Political Economy, vol. 59, no. 3, p. 185-193

Svensson, G. (2004): "Vulnerability in business relationships: the gap between dependence and trust,” The Journal of Business \& Industrial Marketing, vol. 19, no. 7, p. 469-482

Svensson, G. (2002): "A typology of vulnerability scenarios towards suppliers and customers in supply chains based upon perceived time and relationship dependencies," International Journal of Physical Distribution \& Logistics Management, vol. 32, no. 3/4, p. 168 
U.S. International Trade Commission: Air and Noise Pollution Abatement Services: An Examination of U.S. and Foreign Markets, April 2005

Vargo, Stephen L. et R. F. Lusch (2004): “Evolving to a new dominant logic for marketing,” Journal of Marketing, vol. 68, p. 1-17

Walls,M. (2003), "The role of economics in extended producer responsibility: making policy choices and setting policy goals,” Resources for the Future Discussion Paper 03-11

Walter, A., T. Ritter et al. (2001): "Value creation in buyer-seller relationships: Theoretical considerations and empirical results from a supplier's perspective,” Industrial Marketing Management, vol. 30, no. 4, p. 365-377

Weber, Libby and Kyle J. Mayer (2011): "Designing effective contracts: exploring the influence of framing and expectations," Academy of Management Review, vol. 36, no. 1, p. 53-75

Williamson, Oliver E. (1983), “Credible Commitments: Using Hostages to Support Exchange,” American Economic Review, vol. 73, no. 4, p. 519-40

Williamson, Oliver E. (1985): The Economic Institutions of Capitalism, The Free Press

Wilson, David T. (1995): “An integrated model of buyer-seller relationship,” Journal of Academy of Marketing Science, vol. 23, no. 4, p. 330-347

Woodruff, R. B. (1997): "Customer value: The next source for competitive advantage," Journal of the Academy of Marketing Science, vol. 25, no. 2, p. 139-153 